\title{
Hydrochemical properties of the Aral Sea water in summer 2002
}

\author{
J. Friedrich ${ }^{\mathrm{a}, \mathrm{b}, *}$, H. Oberhänsli ${ }^{\mathrm{b}}$ \\ a Alfred Wegener Institute for Polar and Marine Research, Geosystem, Am Handelshafen 12, Bremerhaven D-27570, Germany \\ ${ }^{\mathrm{b}}$ GeoForschungsZentrum Potsdam, Telegrafenberg, D-14773, Potsdam, Germany
}

Received 7 May 2003; accepted 31 December 2003

Available online 16 March 2004

\begin{abstract}
In August 2002, new hydrochemical and hydrophysical data were collected in the Aral Sea. The survey includes crosssections in three locations: within the Small Aral close to Tastubek Bay, in the Large Aral at the northern tip that is Tschebas Bay and within the western basin at Chernishov Bay. All three locations represent different stages in the hydrochemical evolution of the Aral Sea.

Depth profiles of pressure, temperature, conductivity, $\mathrm{pH}$ and dissolved oxygen were measured with a YSI 6600 profiler. Water samples were taken with a Niskin bottle and analyzed for dissolved oxygen and nutrients by standard photometric methods. Major anions and cations were analyzed by ion chromatography and ICP-OES, respectively. Benthic flux experiments were carried out with sediment cores in a batch mode assay on-site.

In the Small Aral, the changes in the hydrochemical properties are not as dramatic as in the Large Aral. The Small Aral represents a brackish inland water body with salinities of $17-18 \mathrm{~g} \mathrm{~kg}^{-1}$. The wind-mixed layer reached $8 \mathrm{~m}$ during the survey. The salinity is vertically and horizontally almost uniform. Below $8 \mathrm{~m}$, a temporally hypoxic layer forms during summer. Salt redissolution was found to be an important source of salt in the water. About $33.5 \mathrm{~g} \mathrm{SO}_{4}^{2-} \mathrm{m}^{-2}$ day $^{-1}$ and about $30.7 \mathrm{~g} \mathrm{Cl}^{-} \mathrm{m}^{-2}$ day $^{-1}$ are released from the sediment in summer.

In the Large Aral, the salinity distribution is uniform in shallow waters (less than $5 \mathrm{~m}$ ) but varies strongly in deeper water. Tschebas Bay at the northern tip of the large Aral represents a shallow lagoon with a maximum depth of about $6 \mathrm{~m}$. The water column was well mixed down to the bottom $(\sim 6 \mathrm{~m})$ having salt concentrations of $82 \mathrm{~g} \mathrm{~kg}^{-1}$ on average. Almost no gradients in dissolved substances were observed. It is suspected that salinity is balanced by fresher water inflow originating from the Syr Darya flowing south and by groundwater exfiltration. Chernishov Bay in the north of the western basin is meromictic. Below a windmixed layer, a very strong pycnocline of $20 \mathrm{~g} \mathrm{~kg}^{-1}$ per $\mathrm{m}$ at $5 \mathrm{~m}$ depth isolates the water below from exchanges with the water above and led to the formation of huge anoxic water body down to the bottom at about $25 \mathrm{~m}$ depth. Below $10 \mathrm{~m}$, the water contains hydrogen sulphide. The salt concentration increases from $82 \mathrm{~g} \mathrm{~kg}^{-1}$ in the surface water to $110 \mathrm{~g} \mathrm{~kg}^{-1}$ at depth. The salt release from the sediment is as high as $1143 \mathrm{~g} \mathrm{SO}_{4}^{2-} \mathrm{m}^{-2}$ day $^{-1}$ and $1626 \mathrm{~g} \mathrm{Cl}^{-} \mathrm{m}^{-2}$ day $^{-1}$. Benthic release of salt is considered as an important source for salt in the bottom water of the western basin and in sustaining the stable density stratification.
\end{abstract}

(c) 2004 Elsevier B.V. All rights reserved.

Keywords: Saline lake; Hydrochemistry; Desiccation; Anoxia; Benthic flux; Asia; Kazakhstan; Aral Sea

* Corresponding author. Alfred Wegener Institute for Polar and Marine Research, Geosystem, Am Handelshafen 12, Bremerhaven D-27570, Germany.

E-mail addresses: jfriedrich@awi-bremerhaven.de (J. Friedrich), oberh@gfz-potsdam.de (H. Oberhänsli). 


\section{Introduction}

In the geologic past, there were times when the Aral Basin in Central Asia was filled with water due to transgressions of the bordering seas like the Black Sea and the Caspian, and there also were times of complete drying out, like for much of the Pleistocene (Boomer et al., 2000). Since the basin became disconnected from the seas, the sea level has then been tightly linked to the runoff from its main inflowing rivers, the Amu Darya and the Syr Darya. The location of the Aral Sea in an endorheic basin makes the system highly responsive to both human activities and climatic variation that alter inflows. The rich archaeological record of the region gives evidence of human-induced regressions of the Aral Sea due to irrigation already $\mathrm{BC}$, and of controlling the inflow of the Amu Darya during the medieval period (Boomer et al., 2000). The most recent regression of the Aral Sea since the 1960s shows impressively how human activities may speed up natural processes. The sea level decreased rapidly within 40 years due to man-induced river regulations and climatic-induced fluctuations in the river's discharges. In 1989, the ongoing desiccation led to the separation of the northern part of the Aral Sea and the big southern part. Nowadays, the western basin and the eastern basin of the Large Aral are connected only by a small channel.

Despite public interest in the Aral Sea's catastrophe, very little in situ data are available. However, to be able to predict the responses of the ecosystem to the fluctuations of the water level and to assess its state requires an understanding of the water chemistry and the benthic fluxes in the lake. The purpose of this paper is to provide ground truth data on the chemical composition of the Aral Sea that are urgently needed to validate and force models. This study was realized conjointly with the INTAS 001030 CLIMAN "Holocene climatic variability and evolution of human settlement in the Aral Sea Basin".

The three locations at the Aral Sea that were part of our survey during the summer campaign of the CLIMAN project revealed an inland sea with retreating coastlines. However, none of the locations, besides desiccation, gave evidence of heavy deterioration due to environmental pollution. In contrast, they gave evidence of being far off from human civilization.

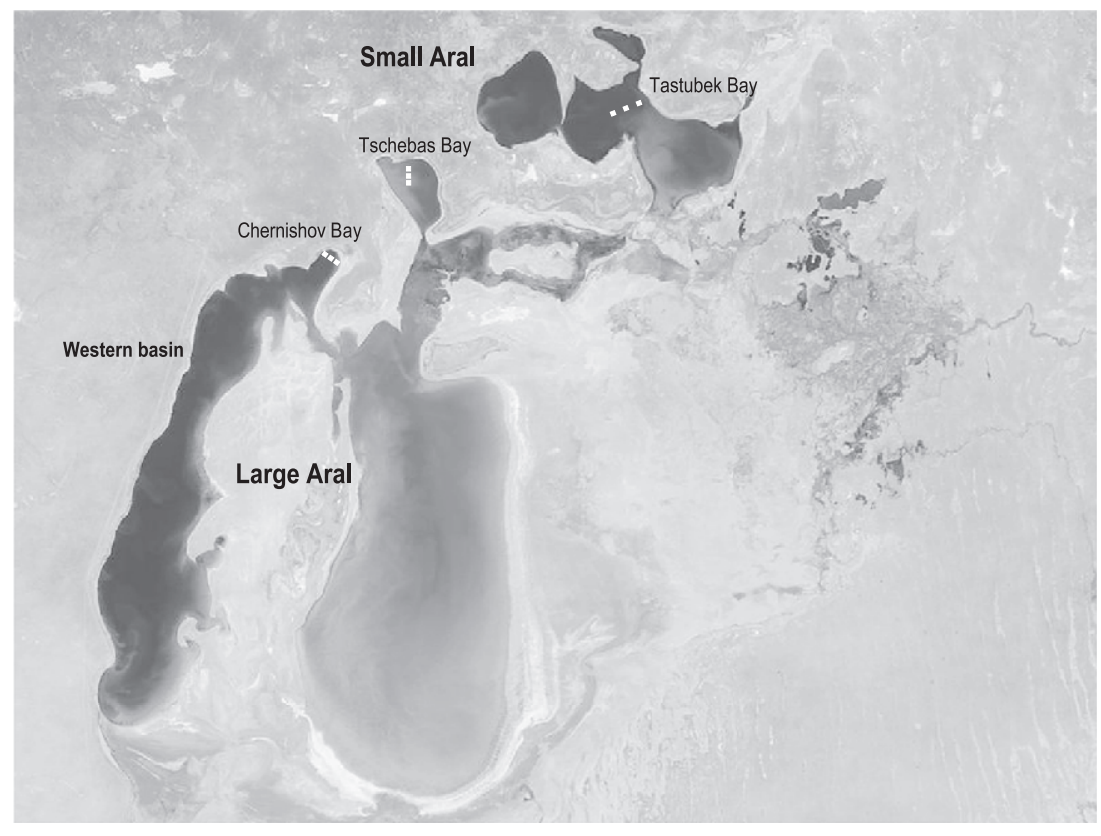

Fig. 1. Satellite image of the Aral Sea in early September 2002 (MODIS 17/09/2002). The sampled stations are indicated by white dots. 
Table 1

Distribution of major anions and cations in the Aral Sea [in $\mathrm{g} \mathrm{kg}^{-1}$ ], August 2003

\begin{tabular}{|c|c|c|c|c|c|c|c|c|c|c|c|c|c|}
\hline Station & $\begin{array}{l}\text { Latitude } \\
\text { north }\end{array}$ & $\begin{array}{l}\text { Longitude } \\
\text { east }\end{array}$ & $\mathrm{pH}$ & $\begin{array}{l}\mathrm{Cl}^{-} \\
{\left[\mathrm{g} \mathrm{kg}^{-1}\right]}\end{array}$ & $\begin{array}{l}\mathrm{SO}_{4}^{2-} \\
{\left[\mathrm{g} \mathrm{kg}^{-1}\right]}\end{array}$ & $\begin{array}{l}\mathrm{HCO}_{3}^{-} \\
{\left[\mathrm{g} \mathrm{kg}^{-1}\right]}\end{array}$ & $\begin{array}{l}\mathrm{F}^{-} \\
{\left[\mathrm{g} \mathrm{kg}^{-1}\right]}\end{array}$ & $\begin{array}{l}\mathrm{Br}^{-} \\
{\left[\mathrm{g} \mathrm{kg}^{-1}\right]}\end{array}$ & $\begin{array}{l}\mathrm{Na}^{+} \\
{\left[\mathrm{g} \mathrm{kg}^{-1}\right]}\end{array}$ & $\begin{array}{l}\mathrm{Mg}^{2+} \\
{\left[\mathrm{g} \mathrm{kg}^{-1}\right]}\end{array}$ & $\begin{array}{l}\mathrm{Ca}^{2+} \\
{\left[\mathrm{g} \mathrm{kg}^{-1}\right]}\end{array}$ & $\begin{array}{l}\mathrm{K}^{+} \\
{\left[\mathrm{g} \mathrm{kg}^{-1}\right]}\end{array}$ & $\begin{array}{l}\mathrm{Sr}^{2+} \\
{\left[\mathrm{g} \mathrm{kg}^{-1}\right.}\end{array}$ \\
\hline \multicolumn{14}{|c|}{ Tastubek Bay } \\
\hline Station I & $46^{\circ} 33.673$ & $60^{\circ} 44.159$ & & & & & & & & & & & \\
\hline $0 \mathrm{~m}$ & & & 8.39 & 5.938 & 6.079 & 0.218 & 0.003 & 0.002 & 3.730 & 1.010 & 0.558 & 0.208 & 0.020 \\
\hline $2 \mathrm{~m}$ & & & 8.37 & 5.891 & 6.049 & 0.218 & 0.003 & 0.002 & 3.700 & 1.000 & 0.548 & 0.200 & 0.019 \\
\hline $6 \mathrm{~m}$ & & & 8.33 & 5.973 & 6.108 & 0.221 & 0.003 & 0.002 & 3.810 & 1.020 & 0.557 & 0.209 & 0.020 \\
\hline $7 \mathrm{~m}$ & & & 8.34 & 5.920 & 6.065 & 0.218 & 0.003 & 0.002 & 3.710 & 0.994 & 0.544 & 0.201 & 0.019 \\
\hline Station II & $46^{\circ} 33.212$ & $60^{\circ} 42.054$ & & & & & & & & & & & \\
\hline $0 \mathrm{~m}$ & & & 8.47 & 5.957 & 6.112 & 0.214 & 0.003 & 0.002 & 3.740 & 1.020 & 0.559 & 0.200 & 0.020 \\
\hline $2 \mathrm{~m}$ & & & 8.45 & 5.934 & 6.089 & 0.215 & 0.003 & 0.002 & 3.660 & 0.998 & 0.549 & 0.196 & 0.019 \\
\hline $4 \mathrm{~m}$ & & & 8.44 & 5.903 & 6.063 & 0.217 & 0.003 & 0.002 & 3.560 & 0.963 & 0.529 & 0.195 & 0.019 \\
\hline $8 \mathrm{~m}$ & & & 8.29 & 5.988 & 6.130 & 0.207 & 0.003 & 0.002 & 3.930 & 1.060 & 0.579 & 0.216 & 0.020 \\
\hline $10 \mathrm{~m}$ & & & 8.09 & 5.925 & 6.073 & 0.224 & 0.003 & 0.002 & 3.810 & 1.030 & 0.563 & 0.202 & 0.020 \\
\hline Station III & $46^{\circ} 33.164$ & $60^{\circ} 41.890$ & & & & & & & & & & & \\
\hline $0 \mathrm{~m}$ & & & 8.49 & 5.981 & 6.110 & 0.214 & 0.003 & 0.002 & 3.540 & 0.957 & 0.527 & 0.191 & 0.018 \\
\hline $2 \mathrm{~m}$ & & & 8.49 & 5.940 & 6.086 & 0.218 & 0.003 & 0.002 & 3.420 & 0.934 & 0.516 & 0.184 & 0.018 \\
\hline $4 \mathrm{~m}$ & & & 8.49 & 5.916 & 6.078 & 0.214 & 0.003 & 0.002 & 3.190 & 0.872 & 0.484 & 0.177 & 0.017 \\
\hline $8 \mathrm{~m}$ & & & 8.49 & 5.952 & 6.098 & 0.214 & 0.003 & 0.002 & 3.030 & 0.840 & 0.465 & 0.161 & 0.016 \\
\hline $10 \mathrm{~m}$ & & & 8.34 & 5.982 & 6.133 & 0.215 & 0.003 & 0.002 & 2.940 & 0.817 & 0.450 & 0.165 & 0.016 \\
\hline
\end{tabular}

Tschebas Bay

Station IV $\quad 46^{\circ} 17.96959^{\circ} 40.040$

$\begin{array}{lrrrrrrrrrrrr}0 \mathrm{~m} & & 8.21 & 31.620 & 24.085 & 0.430 & 0.012 & <0.009 & 18.500 & 5.275 & 0.753 & 1.070 & 0.056 \\ \text { Station V } & 46^{\circ} 18.476 & 59^{\circ} 39.561 & & & & & & & & & & \\ 0 \mathrm{~m} & & 8.24 & 31.650 & 24.200 & 0.429 & 0.012 & 0.009 & 18.100 & 5.250 & 0.745 & 1.195 & 0.055 \\ 2 \mathrm{~m} & & 8.25 & 31.605 & 24.125 & 0.430 & 0.012 & <0.009 & 18.900 & 5.250 & 0.748 & 1.195 & 0.055 \\ 4 \mathrm{~m} & & 8.26 & 31.345 & 24.070 & 0.433 & 0.012 & 0.009 & 18.800 & 5.225 & 0.743 & 1.185 & 0.055 \\ 6 \mathrm{~m} & & 8.27 & 32.700 & 24.940 & 0.430 & 0.012 & <0.009 & 18.800 & 5.175 & 0.738 & 1.180 & 0.055 \\ \text { Station VI } & 46^{\circ} 17.893 & 59^{\circ} 40.002 & & & & & & & & & & \\ 0 \mathrm{~m} & & 8.28 & 31.520 & 24.010 & 0.430 & 0.012 & <0.009 & 19.200 & 5.250 & 0.755 & 1.068 & 0.056 \\ 2 \mathrm{~m} & & 8.27 & 31.385 & 24.005 & 0.430 & 0.012 & <0.009 & 19.500 & 5.225 & 0.745 & 1.063 & 0.055 \\ 4 \mathrm{~m} & & 8.27 & 31.250 & 23.905 & 0.430 & 0.012 & <0.009 & 19.200 & 5.200 & 0.750 & 1.065 & 0.055 \\ 6 \mathrm{~m} & & 8.28 & 31.405 & 23.995 & 0.415 & 0.012 & <0.009 & 19.500 & 5.275 & 0.760 & 1.208 & 0.056\end{array}$

Chernishov Bay

Station VII $\quad 45^{\circ} 59.37359^{\circ} 14.027$

\begin{tabular}{|c|c|c|c|c|c|c|c|c|c|c|c|c|}
\hline $0 \mathrm{~m}$ & & 8.23 & 31.575 & 24.625 & 0.412 & 0.012 & $<0.009$ & 18.400 & 5.200 & 0.753 & 1.220 & 0.059 \\
\hline Station VIII & $45^{\circ} 59.33359^{\circ} 14.288$ & & & & & & & & & & & \\
\hline $0 \mathrm{~m}$ & & 8.24 & 31.795 & 24.670 & 0.415 & 0.013 & $<0.009$ & 18.900 & 5.150 & 0.743 & 1.208 & 0.059 \\
\hline $\mathrm{m}$ & & 8.23 & 31.575 & 24.595 & 0.416 & 0.013 & $<0.009$ & 19.500 & 5.225 & 0.755 & 1.223 & 0.059 \\
\hline $\mathrm{m}$ & & 8.18 & 35.750 & 27.385 & 0.459 & 0.014 & $<0.009$ & 22.300 & 5.900 & 0.710 & 1.378 & 0.059 \\
\hline $\mathrm{m}$ & & 8.11 & 37.570 & 28.355 & 0.480 & 0.014 & 0.010 & 22.600 & 6.225 & 0.678 & 1.453 & 0.059 \\
\hline $0 \mathrm{~m}$ & & 8.08 & 38.615 & 29.030 & 0.488 & 0.015 & $<0.009$ & 22.700 & 6.350 & 0.673 & 1.478 & 0.059 \\
\hline tation IX & $45^{\circ} 59.07659^{\circ} 14.844$ & & & & & & & & & & & \\
\hline $\mathrm{m}$ & & 8.2 & 31.310 & 24.265 & 0.410 & 0.013 & $<0.009$ & 19.300 & 5.100 & 0.753 & 1.073 & 0.059 \\
\hline $\mathrm{m}$ & & 8.2 & 33.975 & 26.240 & 0.435 & 0.013 & $<0.009$ & 20.500 & 5.550 & 0.748 & 1.040 & 0.059 \\
\hline $0 \mathrm{~m}$ & & 8.06 & 38.370 & 28.825 & 0.486 & 0.017 & $<0.009$ & 24.300 & 6.350 & 0.678 & 1.320 & 0.060 \\
\hline $5 \mathrm{~m}$ & & 8.11 & 40.505 & 30.670 & 0.508 & 0.015 & $<0.009$ & 25.000 & 6.775 & 0.698 & 1.393 & 0.061 \\
\hline $22 \mathrm{~m}$ & & 8.15 & 41.970 & 31.965 & 0.514 & 0.016 & $<0.009$ & 25.700 & 6.925 & 0.695 & 1.405 & 0.061 \\
\hline Aral in $1947^{*}$ & & $7.8-8$ & 3.5 & 3.31 & 0.19 & & 0.003 & 2.26 & 0.49 & 0.56 & 0.08 & \\
\hline
\end{tabular}

Chemical composition of the water column in Tastubek Bay, Tschebas Bay and Chernishov Bay.

Tastubek Bay refers to the Small Aral; Tschebas Bay and Chernishov Bay refers to the western basin of the Large Aral.

At the end of the table, the concentration of some components (in $\mathrm{g}^{-1}$ ) in the $1940 \mathrm{~s}$ are given for comparison, marked with *(after Blinov, 1947 from Letolle and Mainguet, 1996). 

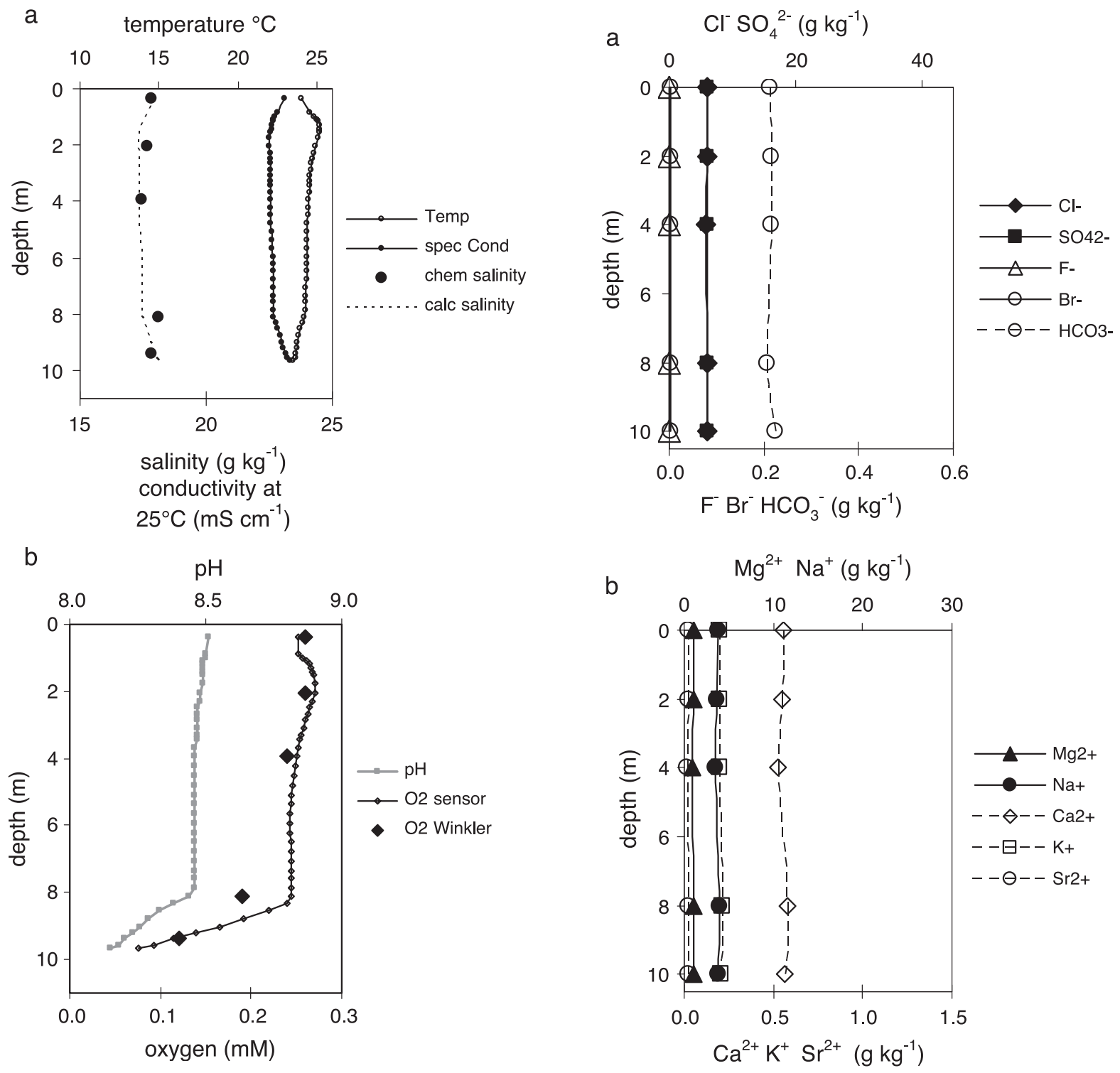

Fig. 2. Small Aral, Tastubek Bay, station II. Vertical profiles of (a) temperature $\left({ }^{\circ} \mathrm{C}\right)$, specific conductivity $\left(\mathrm{mS} \mathrm{cm} \mathrm{cm}^{-1}\right)$, chemically determined salinity $\left(\mathrm{g} \mathrm{kg}^{-1}\right)$ and salinity calculated from conductivity $\left(\mathrm{g} \mathrm{kg}^{-1}\right)$, and (b) $\mathrm{pH}$, dissolved oxygen measured with a YSI probe $\left(\mathrm{O}_{2}\right.$ sensor, in $\left.\mathrm{mM}\right)$ and dissolved oxygen measured by Winkler titration $\left(\mathrm{O}_{2}\right.$ Winkler, in $\left.\mathrm{mM}\right)$.

\section{Material and methods}

During the geochemical survey in August 2002, cross-sections in three locations were sampled: within the Small Aral close to Tastubek Bay, in

Fig. 3. Small Aral, Tastubek Bay, station II. Vertical distribution of (a) major anions in $\mathrm{g} \mathrm{kg}^{-1}$ and (b) major cations in $\mathrm{g} \mathrm{kg}^{-1}$.

the Large Aral the northern tip-Tschebas Bay and within the western basin at Chernishov Bay (Fig. 1). At each location, along the cross-sections, three vertical profiles were sampled. The open water was reached by a pontoon equipped with a tripod and winches.

Depth profiles of pressure, temperature, conductivity, $\mathrm{pH}$ and dissolved oxygen were measured 


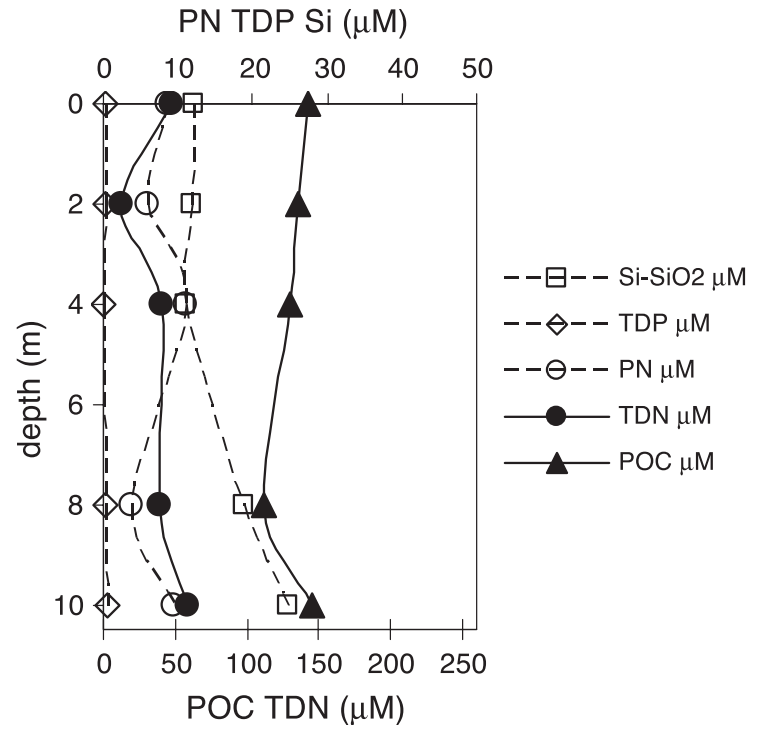

Fig. 4. Small Aral, Tastubek Bay, station II. Vertical distribution of particulate nitrogen $(\mathrm{PN})$, particulate organic carbon (POC), total dissolved nitrogen (TDN), total dissolved phosphorus (TDP) and dissolved silica (all in $\mu \mathrm{M}$ ).

with a YSI 6600 profiler. Since conventional relations of conductivity, temperature and salinity in seawater used to convert conductivity to salinity are not valid for Aral Sea water due to higher salinity and different ionic composition, an empiric relationship was used to transfer specific conductivity into salinity. The ionic composition of the water samples taken was analyzed as described below, and specific conductivity was measured in the lab. With a linear relationship of chemically determined salinity and lab conductivity in the water samples $\left(r^{2}>0.92\right)$, the in situ YSI conductivity values where transformed into salinity (psu). Water samples were taken with a Niskin bottle and analyzed subsequently to sampling on-shore for dissolved oxygen by the Winkler method and for ammonia by the phenylhypochlorite method with a spectrophotometer (Spectroquant Nova 60 A). Major anions and cations were analyzed by ion chromatography and ICP-OES, respectively. Total dissolved phosphorus (TDP) and total dissolved nitrogen (TDN) were measured photometrically after peroxodisulphate digestion with the ammoniummolybdate method and with the 2,6-dimethylphenol method as nitrate on a "PROCON" autoanalyzer, respectively. Dissolved silica was analyzed photometrically (Spectroquant Nova $60 \mathrm{~A}$ ) with the molybdenum blue method. Particulate organic carbon (POC) and particulate nitrogen (PN) in the suspended particulate matter were measured with a $\mathrm{C} / \mathrm{N}$ analyzer (Elementar, Vario El) after filtering $60 \mathrm{ml}$ water onto precombusted GF-F filters. $\mathrm{C} / \mathrm{N}$ ratios in this paper represent the molar ratios of the concentrations of carbon and nitrogen.

Benthic flux experiments on sediment cores were carried out in a batch mode assay. At each location, four sediment cores $(6 \mathrm{~cm}$ diameter) were placed in an incubation tank filled with bottom water of the same station. One core was equipped with an $\mathrm{O}_{2}$ probe to measure oxygen consumption, and three replicate cores were used for sampling. The sediment surfaces of the cores were adjusted to have approximately $9 \mathrm{~cm}$ of sediment and 13 $\mathrm{cm}$ of overlaying water. The overlaying water was stirred with a magnetic stirrer at about $1 \mathrm{rps}$. During the $5 \mathrm{~h}$ experiment, the cores were stored in the dark at in situ temperatures $\left(28,20,25{ }^{\circ} \mathrm{C}\right.$ for Tastubek Bay, Tschebas Bay and Chernishov Bay, respectively). The sediment overlaying water was sampled every hour. Aliquots of $5 \mathrm{ml}$ were transferred in vials for sulphate, TDP, TDN and ammonia analysis.

Table 2

Benthic fluxes [in mmol m${ }^{-2}$ day $^{-1}$ ]

\begin{tabular}{|c|c|c|c|c|c|c|}
\hline & $\mathrm{O}_{2}$ & TDN & $\mathrm{NH}_{4}^{+}$ & TDP & $\mathrm{SO}_{4}^{2-}$ & $\mathrm{Cl}^{-}$ \\
\hline Tastubek Bay & $-61 \pm 6$ & $35 \pm 10$ & $20 \pm 13$ & $0.13 \pm 0.01$ & $349 \pm 133$ & $866 \pm 387$ \\
\hline Tschebas Bay & $-26 \pm 3$ & $21 \pm 5$ & $0.9 \pm 0.2$ & $0.2 \pm 0.09$ & $2364 \pm 702$ & $9410 \pm 2419$ \\
\hline Chernishov Bay & $-64 \pm 7$ & & $4 \pm 3$ & $1 \pm 0.9$ & $11,988 \pm 4832$ & $45,866 \pm 17,124$ \\
\hline
\end{tabular}

Negative fluxes indicate consumption. The standard deviation is given for each flux. 


\subsection{Flux calculation}

Benthic fluxes were calculated by a linear fit of the concentration changes versus time. Fluxes, $F$, in mmol $\mathrm{m}^{-2}$ day ${ }^{-1}$, were then calculated according to:

$F_{\text {benthic }}=h \frac{\partial C}{\partial t}$

where $h$ is the height $(\mathrm{dm})$ of the enclosed water column in the core, and $\partial C / \partial t\left(\mathrm{mmol} \mathrm{dm}{ }^{-3}\right.$ day $\left.^{-1}\right)$ represents the accumulation rate of a compound.

\section{Results}

The data of the 2002 summer survey are given according to the sampled locations in Table 1. First, the physical properties, second, the chemical properties and, third, the benthic fluxes will be discussed. Because the lateral distribution in the physical and chemical properties does not vary much within a cross-section, one representative profile is displayed in the figures.

\subsection{Tastubek Bay}

The northern part of the Small Aral is shallow. Echo sounding revealed a maximum depth of about $15 \mathrm{~m}$. The water column is mixed by wind-driven circulation down to a depth of $8 \mathrm{~m}$ (Fig. 2a). During calm weather, a small inverse conductivity gradient developed in the upper $2 \mathrm{~m}$ with values $\sim 1 \mathrm{mS} \mathrm{cm} \mathrm{cm}^{-1}$ higher than those down to $8 \mathrm{~m}$, probably due to evaporation at the surface. Below $8 \mathrm{~m}$ depth, an increase of conductivity of about $1 \mathrm{mS} \mathrm{cm}-1$ was observed, accompanied by a decrease in dissolved oxygen and $\mathrm{pH}$ (Fig. 2b). The salinity distribution is vertically and horizontally almost uniform, with total salt concentrations of about $17-18 \mathrm{~g} \mathrm{~kg}^{-1}$. The sulphate concentration equals the chloride concentration (Fig. 3a). The $\mathrm{SO}_{4} / \mathrm{Cl}$ mass ratio is horizontally and vertically uniform with a value of 1.02 . Major cations are sodium and magnesium (Fig. 3b). The nutrient profiles reflect an accumulation of organic matter at the surface and in the bottom layer. The decreasing concentration in dissolved oxygen and $\mathrm{pH}$ in the near bottom water and an increase in nutrient concentrations (Fig. 4) indicate intense benthic recycling and reduced exchange with the upper water layer. Benthic flux experiments revealed oxygen consumption rates of $61 \mathrm{mmol}$ $\mathrm{m}^{-2}$ day $^{-1}$ (Table 2). The flux of total dissolved
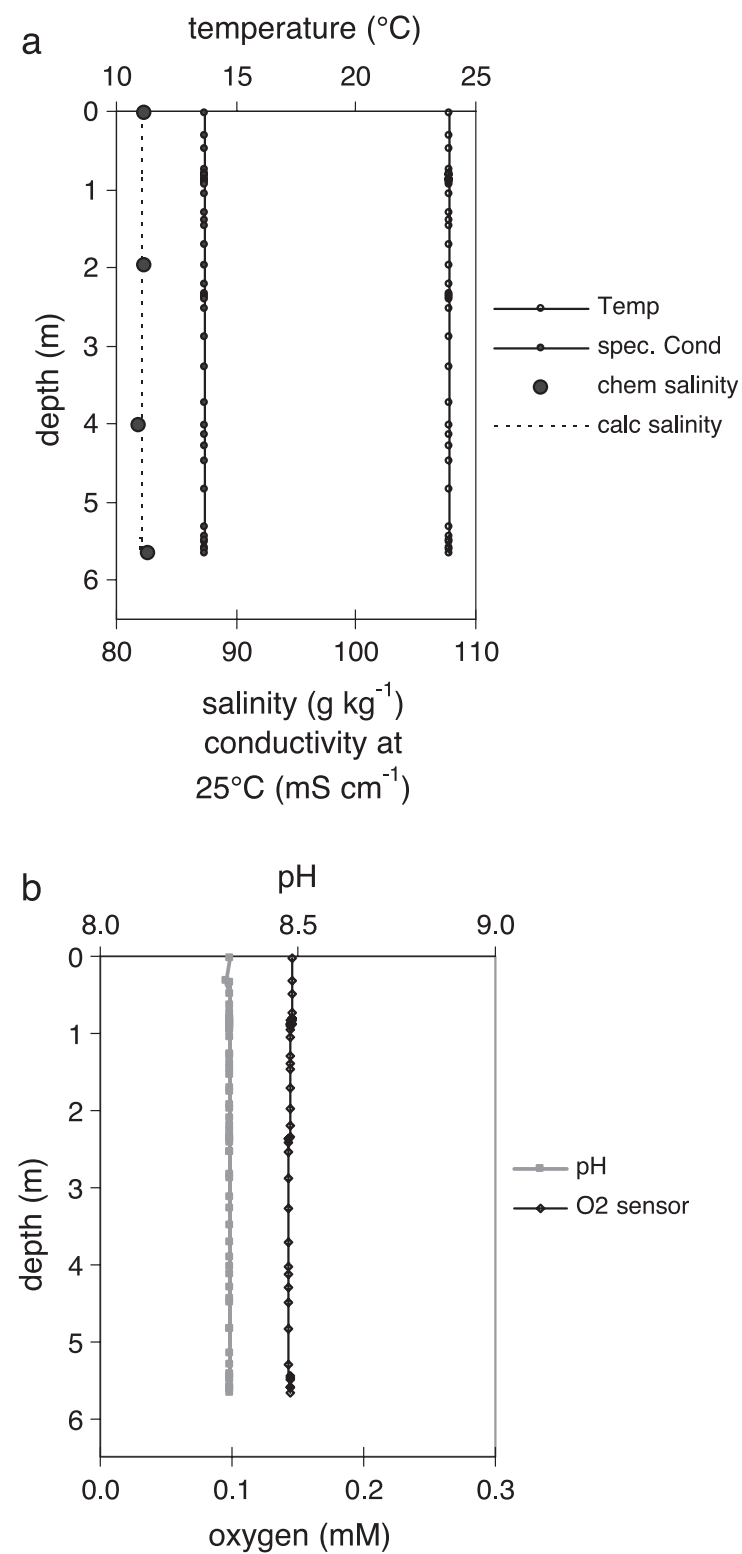

Fig. 5. (a) Large Aral, Tschebas Bay, station VI. Vertical profiles of (a) temperature $\left({ }^{\circ} \mathrm{C}\right)$, specific conductivity $\left(\mathrm{mS} \mathrm{cm}^{-1}\right)$, chemically determined salinity $\left(\mathrm{g} \mathrm{kg}^{-1}\right)$ and salinity calculated from conductivity $\left(\mathrm{g} \mathrm{kg}^{-1}\right)$, and (b) $\mathrm{pH}$ and dissolved oxygen measured with a YSI probe $\left(\mathrm{O}_{2}\right.$ sensor, in $\left.\mathrm{mM}\right)$. 

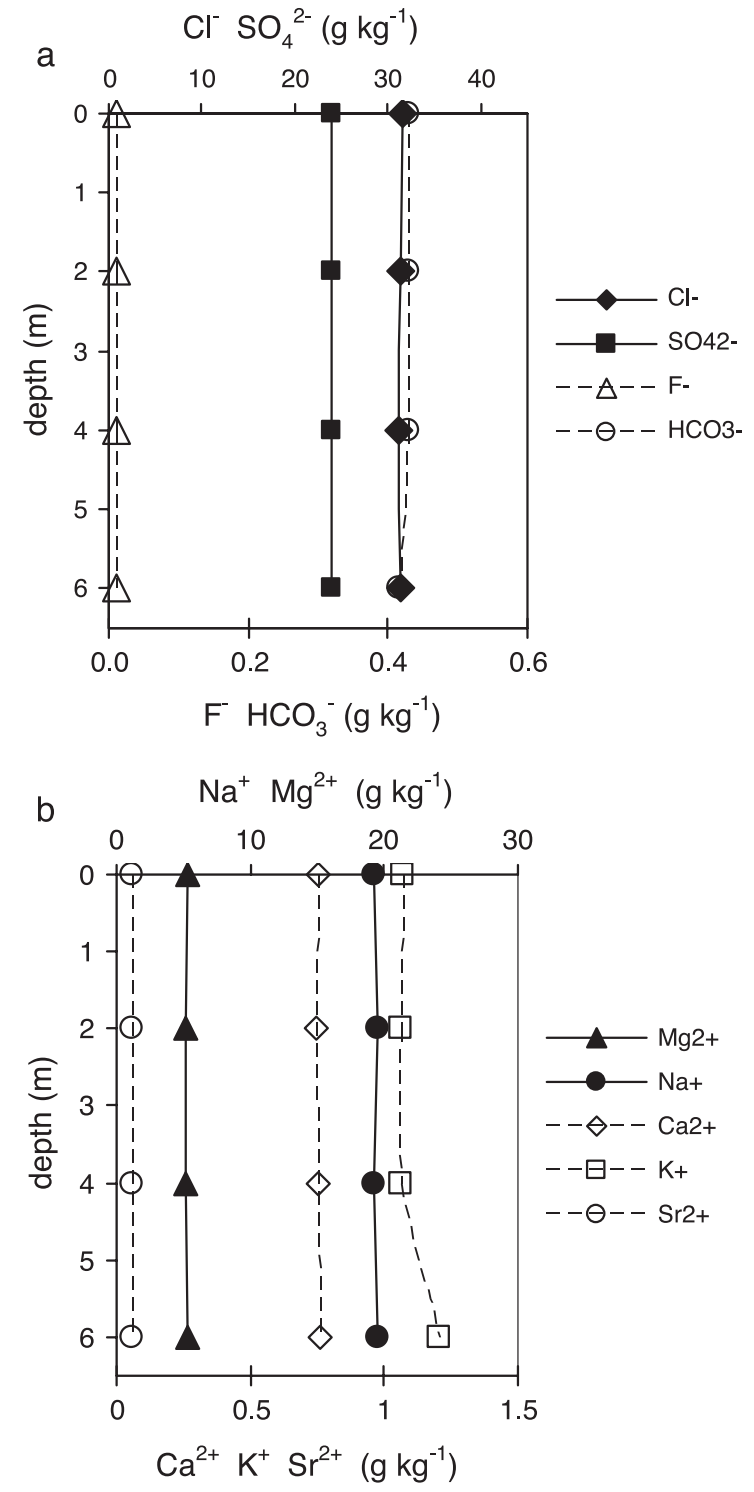

Fig. 6. Large Aral, Tschebas Bay, station VI. Vertical distribution of (a) major anions in $\mathrm{g} \mathrm{kg}^{-1}$ and (b) major cations in $\mathrm{g} \mathrm{kg}^{-1}$.

nitrogen out of the sediment was about $35 \mathrm{mmol}$ $\mathrm{m}^{-2}$ day $^{-1}$. The phosphorus flux from the sediment remained low $\left(0.1 \mathrm{mmol} \mathrm{m}^{-2}\right.$ day $\left.^{-1}\right)$ because anaerobic conditions were not reached during the experiment. We measured a redissolution of sulphate and chloride from the sediment to the water column of 349 and $866 \mathrm{mmol} \mathrm{m}^{-2}$ day $^{-1}$, respectively. The $\mathrm{SO}_{4} / \mathrm{Cl}$ mass ratio of the flux was 1.09 .

\subsection{Tschebas Bay}

Tschebas Bay at the northern tip of the Large Aral represents a shallow lagoon with a maximum depth of about $6 \mathrm{~m}$. The water column was well mixed down to the bottom. Almost no gradients in dissolved substances were observed (Figs. 5a,b, 6a,b and 7). Salt concentration $\left(\sim 82 \mathrm{~g} \mathrm{~kg}^{-1}\right)$ is considerably elevated compared to the Small Aral. In contrast to the Small Aral, the chloride concentration is higher than the sulphate concentration (Fig. 6a). The $\mathrm{SO}_{4} / \mathrm{Cl}$ mass ratio is about 0.76 . A remarkable difference to the water composition in the Small Aral is the concentration of potassium being higher than that of calcium (Fig. 6b). Particulate and dissolved nutrients show highest values in the subsurface and close to the bottom. Benthic flux experiments revealed lower oxygen consumption ( $-26 \mathrm{mmol}$ $\mathrm{m}^{-2}$ day $^{-1}$ ) than in the Small Aral. This seems rather related to the lower temperature during incubation $\left(20{ }^{\circ} \mathrm{C}\right.$ in contrast to $28{ }^{\circ} \mathrm{C}$ in Small Aral) than to lower organic matter availability. SeaWiFS images from July and August 2002 processed for chlorophyll-like pigments indicate $5-10 \mathrm{mg} \mathrm{m}^{-3} \mathrm{chl}$ for Tastubek Bay and $10-15 \mathrm{mg} \mathrm{m}^{-3} \mathrm{chl}$ for Tschebas Bay (Stanichny et al., 2003). Benthic flux

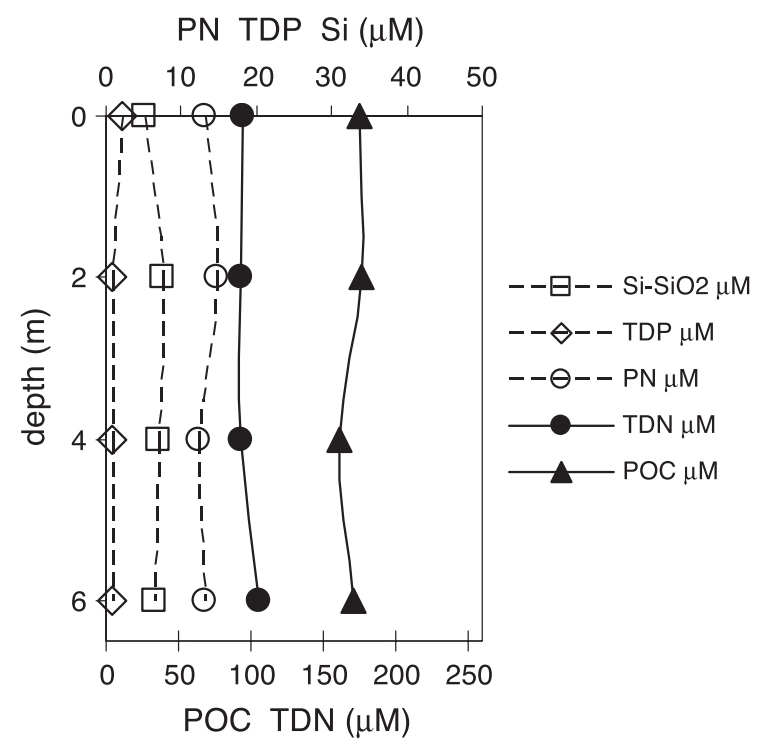

Fig. 7. Large Aral, Tschebas Bay, station VI. Vertical distribution of dissolved and particulate nutrients $(\mu \mathrm{M})$. 

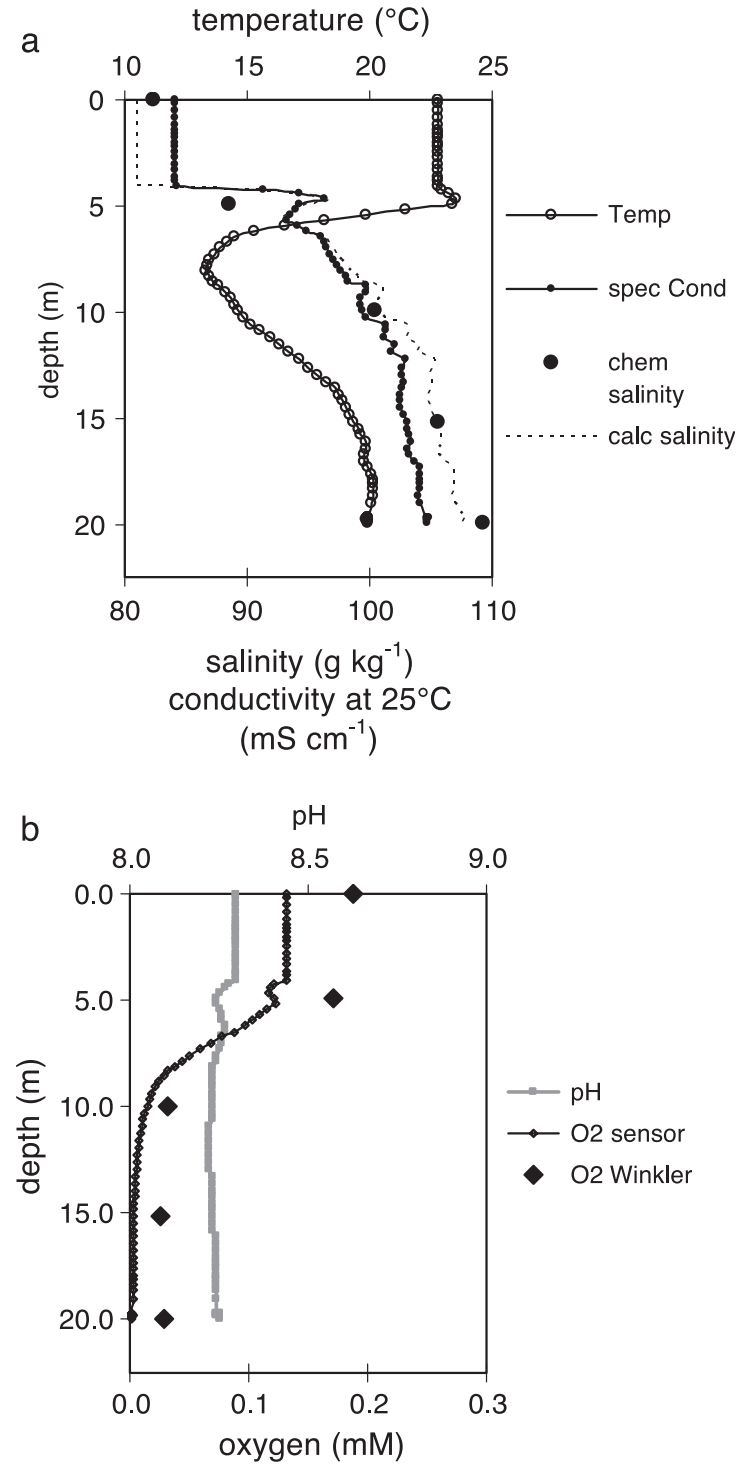

Fig. 8. Large Aral, Chernishov Bay, station IX. Vertical profiles of (a) temperature $\left({ }^{\circ} \mathrm{C}\right)$, specific conductivity $\left(\mathrm{mS} \mathrm{cm}^{-1}\right)$, chemically determined salinity $\left(\mathrm{g} \mathrm{kg}^{-1}\right)$ and salinity calculated from conductivity $\left(\mathrm{g} \mathrm{kg}^{-1}\right)$, and (b) $\mathrm{pH}$ and dissolved oxygen measured with a YSI probe $\left(\mathrm{O}_{2}\right.$ sensor, in $\left.\mathrm{mM}\right)$.

of total dissolved nitrogen and phosphorus out of the sediment amounted to 21 and $0.2 \mathrm{mmol} \mathrm{m}^{-2}$ day $^{-1}$, respectively (Table 2). The benthic flux of sulphate and chloride into the water column was 2364 and $9410 \mathrm{mmol} \mathrm{m}^{-2}$ day $^{-1}$, respectively. The $\mathrm{SO}_{4} / \mathrm{Cl}$ mass ratio of the flux was 0.68 .

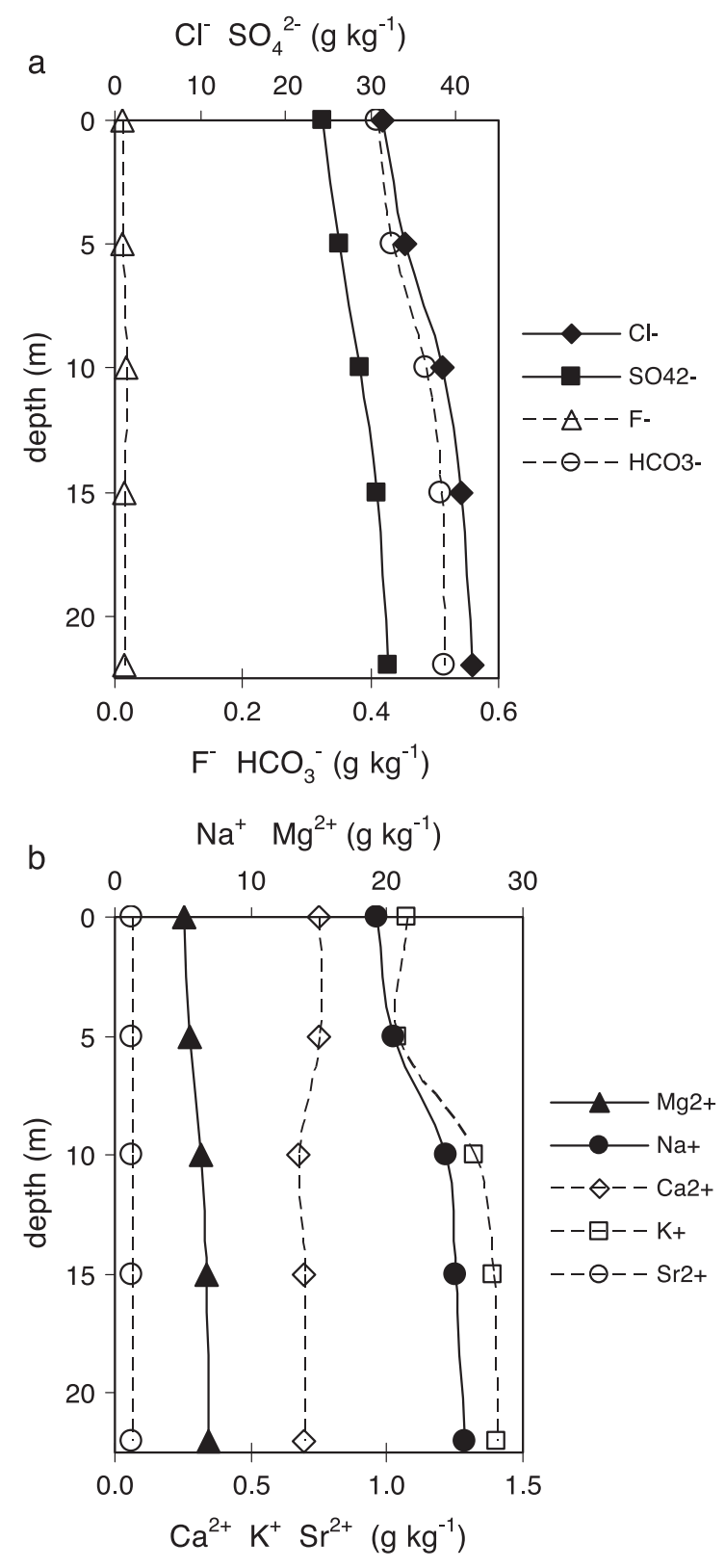

Fig. 9. Large Aral, Chernishov Bay, station IX. Vertical profiles of (a) temperature $\left({ }^{\circ} \mathrm{C}\right)$, specific conductivity $\left(\mathrm{mS} \mathrm{cm}^{-1}\right)$, chemically determined salinity $\left(\mathrm{g} \mathrm{kg}^{-1}\right)$ and salinity calculated from conductivity $\left(\mathrm{g} \mathrm{kg}^{-1}\right)$, and (b) $\mathrm{pH}$ and dissolved oxygen measured with a YSI probe $\left(\mathrm{O}_{2}\right.$ sensor, in $\left.\mathrm{mM}\right)$ and dissolved oxygen measured by Winkler titration $\left(\mathrm{O}_{2}\right.$ Winkler, in $\left.\mathrm{mM}\right)$. 


\subsection{Chernishov Bay}

Echo sounding revealed a shallow shoreline that is followed by a sharp descent of the sea bottom to a $25 \mathrm{~m}$ deep plain. The stratification of the water column seen in summer is due to the development of a stable density gradient below the surface mixed layer. The total salt concentration increases from 82 $\mathrm{g} \mathrm{kg}^{-1}$ in the surface water to $101 \mathrm{~g} \mathrm{~kg}^{-1}$ at $10 \mathrm{~m}$ depth and to $110 \mathrm{~g} \mathrm{~kg}^{-1}$ at the bottom. The $\mathrm{SO}_{4} / \mathrm{Cl}$ mass ratio averages 0.77 in the upper $10 \mathrm{~m}$ and decreases slightly to 0.75 at depth. The warm surface layer $(0-4 \mathrm{~m})$ of moderate salinity is followed by a very warm thin layer, which is accompanied by a drop in oxygen (Fig. 8a and b). The main halocline is located at $4 \mathrm{~m}$ depth. Below the halocline, sulphate, chloride, bicarbonate, as well as potassium, sodium and magnesium increase with depth, whereas calcium decreases (Fig. 9a and b). The concentration of particulate and dissolved nutrients also increases, except for phosphorus (Fig. 10). We suspect that TDP is captured by calcium. At intermediate depth $(5-11 \mathrm{~m})$, a cold stratum with higher conductivity was detected followed by a warm bottom layer with highest conductivity. Below $10 \mathrm{~m}$, the water contains hydrogen sulphide. The low-oxygen solubility in the high saline waters combined with reduced ventilation

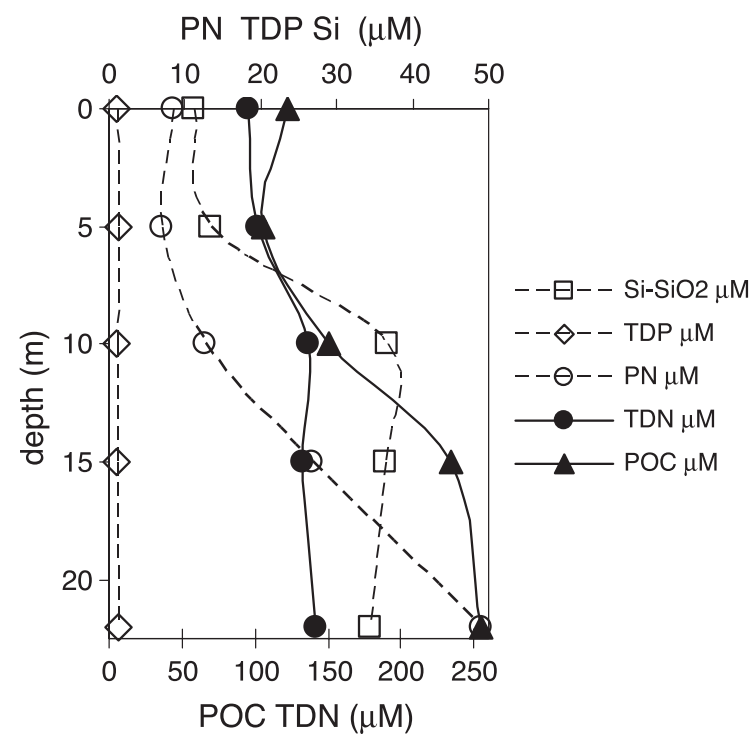

Fig. 10. Large Aral, Chernishov Bay, station IX. Vertical distribution of dissolved and particulate nutrients $(\mu \mathrm{M})$. of the deeper water layers and the oxygen consumption processes cause a decrease in dissolved oxygen to zero between 5 and $13 \mathrm{~m}$ depth. Benthic flux experiments revealed rapid oxygen consumption (-64 mmol $\mathrm{m}^{-2}$ day $^{-1}$, Table 2), followed by subsequent anaerobic decomposition of organic matter. However, we suspect that most of the oxygen introduced to the core during sampling was consumed by the oxidation of reduced substances released from the sediment. Due to anoxic conditions, a considerable flux of ammonia $\left(4 \mathrm{mmol} \mathrm{m}{ }^{-2} \mathrm{day}^{-1}\right)$ and phosphorus was measured $\left(1 \mathrm{mmol} \mathrm{m}^{-2} \mathrm{day}^{-1}\right)$. The benthic flux of sulphate and chloride into the water column was 11,988 and 45,866 $\mathrm{mmol} \mathrm{m}^{-2}$ day ${ }^{-1}$, respectively. The $\mathrm{SO}_{4} / \mathrm{Cl}$ mass ratio of the flux was 0.7 .

\section{Discussion}

The history of the Aral Sea is a history of regressions and transgressions (Shnitnikov, 1983), both climatologically and man-induced. In prehistoric times, salinity and water level were primarily controlled by the regional climate causing changes in the river discharges (Boomer et al., 2000). In historic times, human activities were controlling both lake level and salinity. The most recent regression began in the 1960s, with increasing irrigation followed by decreasing river discharges but also due to decreasing precipitation. Changes in the water level caused severe changes in the water chemistry and the redox milieu of the lake. The water has been getting constantly saltier since then, starting from $10 \mathrm{~g} \mathrm{~kg}^{-1}$ in the early $1960 \mathrm{~s}$ (Micklin, 1988). Estimates of the decrease in volume from satellite images and increase in salinity are in good agreement. Satellite images reveal a decrease in volume by nine times since the 1960s (Stanichny et al., 2003), while the increase in salinity from 10 to $80-90 \mathrm{~g} \mathrm{~kg}^{-1}$ indicates a volume shrinkage by 8 to 9 times.

In 2002, the Aral Sea consisted of almost three separate parts: the northern Small Aral, connected to the Large Aral only via the narrow and shallow Berg strait, and the Large Aral, with its almost disconnected western and the eastern basins, having some water exchange at favorable wind conditions (Zavialov et 
al., 2003) through a shallow channel. These parts of the lake represent different stages of the desiccation process. The Small Aral represents a small and shallow brackish inland water body. The eastern basin is in a shallow lagoon stage with probably the highest salinity. The western basin with its deep trench is meromictic containing anoxic bottom water due to stable density stratification. The ionic composition of the water in all parts is by no means comparable with oceanic water and differs in between the three parts of the Aral Sea. For that reason, the Small Aral and the Large Aral will be discussed separately. The eastern basin of the Large Aral will not be discussed here because it was not part of our survey.

\subsection{Small Aral}

Integration of satellite images (Stanichny et al., 2003) reveals that water level of the Small Aral (approximately $42 \mathrm{~m}$ a.s.1.) has been quite stable since 1989. The corresponding GIS-derived surface area is estimated to be $2930 \mathrm{~km}^{2}$, and the volume calculated from a bathymetrical map is $21.5 \mathrm{~km}^{3}$. The volume then decreased by 3.7 times since the 1960s. The salinity in the Small Aral increased from $10 \mathrm{~g} \mathrm{~kg}^{-1}$ in the 1960 s to $17-18 \mathrm{~g} \mathrm{~kg}^{-1}$ today, suggesting a decrease in volume only by a factor of 1.8. This implies an export of salt perhaps to the Large Aral and dilution by freshwater input from the Syr Darya. The changes in the hydrochemical properties are not as dramatic as in the Large Aral. The $\mathrm{SO}_{4} / \mathrm{Cl}$ mass ratio of average world river water is 1-2 (Seim, 1990). The $\mathrm{SO}_{4} / \mathrm{Cl}$ mass ratio of 1.02 in the Small Aral in 2002 is within this range. In the 1940s, a ratio of 0.95 was reported by Blinov (Letolle and Mainguet, 1996). Taking into account a certain deviation of the values due to different analytical methods, we conclude that not much alteration to $\mathrm{SO}_{4}^{2-}$ and $\mathrm{Cl}^{-}$ occurred. The precipitation of gypsum in the open water, which would have led to a decrease in the ratio, is unlikely because it does not start below salinities of $30 \mathrm{~g} \mathrm{~kg}^{-1}$ according to Brodskaya (Letolle and Mainguet, 1996). Compared to the forties, the $\mathrm{Mg}$ / $\mathrm{Ca}$ ratio increased from 0.88 (Blinov in Letolle and Mainguet, 1996) to 1.8, thus suggesting a depletion of the Aral water in $\mathrm{Ca}$ due to the removal of $\mathrm{Ca}$ during precipitation of calcium carbonate. The $\mathrm{Na} / \mathrm{K}$ ratio did not change much from the 1960 s, then measured at
17.8 (Blinov, 1991) and 18.4 in 2002, which is not much different from Lake Issyk-Kul but much higher than in the rivers in the Tien Shan. We assume that the increase in the $\mathrm{Na} / \mathrm{K}$ ratio from river water to lake water mostly depends on preferential weathering of K-bearing clay minerals.

For comparison, brackish Lake Issyk-Kul in the Tien Shan Mountains, with an average salinity of 6.06 , has a $\mathrm{SO}_{4} / \mathrm{Cl}$ mass ratio of 1.4, a $\mathrm{Mg} / \mathrm{Ca}$ ratio of 2.5 and a $\mathrm{Na} / \mathrm{K}$ ratio of 21.7 ; whereas its surrounding rivers have a $\mathrm{SO}_{4} / \mathrm{Cl}$ mass ratio of 4 , a $\mathrm{Mg} / \mathrm{Ca}$ of $0.1-0.2$ and a $\mathrm{Na} / \mathrm{K}$ ratio of 4 (Vollmer et al., 2002). The $\mathrm{Mg} / \mathrm{Ca}$ ratio is the same as the average world river water ratio reported in Seim (1990).

\subsection{Large Aral}

The Large Aral developed differently. Proportional to its surface, the Large Aral receives less fresh water from river runoff than the Small Aral. Therefore, due to its larger surface, evaporation leads to a faster decrease in the water level. As a result, the desiccation did proceed much faster. The sea level dropped by 0.6 $\mathrm{m}$ annually for time period 1989-2001, on average, with maximum values of $1 \mathrm{~m}$ (Stanichny et al., 2003). In November 2002, the sea level in the western basin of the Large Aral approached the $30.5 \mathrm{~m}$ a.s.l. (Zavialov et al., 2003). GIS-derived surface of the Large Aral, based on satellite images from summer 2002 and accordingly, bathymetry map, derived volume values are as follows (Stanichny, personal communication): the surface area of the Large Aral has shrunk to $17,350 \mathrm{~km}^{2}$ and the lake volume decreased to $109 \mathrm{~km}^{3}$. The western basin with a trench of $40 \mathrm{~m}$ depth contains approximately $76.2 \mathrm{~km}^{3}$ and covers an area of $5210 \mathrm{~km}^{2}$. The shallow eastern basin with a maximum depth of $7 \mathrm{~m}$ contains $32.8 \mathrm{~km}^{3}$ and has an area of $12,140 \mathrm{~km}^{2}$.

The salinity increased to $82 \mathrm{~g} \mathrm{~kg}^{-1}$ in the surface water and to $110 \mathrm{~g} \mathrm{~kg}^{-1}$ in the bottom water in the northwestern edge of the western basin. Zavialov et al. (2003) report the same values for the surface water and $96 \mathrm{~g} \mathrm{~kg}^{-1}$ for the bottom water of the deep trench further south for November 2002. We observed lower $\mathrm{Na} / \mathrm{K}$ ratios (15) in shallow waters close to the shore and higher ratios $(18-20)$ in deeper open waters comparable to those in the Small 
Aral. The low ratios can be explained by early precipitation of sodium sulphates, perhaps in the marginal residual soils (Letolle, personal communication). We also found a considerably lower $\mathrm{SO}_{4} / \mathrm{Cl}$ ratio (0.78) than in the Small Aral, decreasing with depth (0.75), presumably due to the precipitation of gypsum in the open water. During desiccation, the $\mathrm{Mg} / \mathrm{Ca}$ ratio increased considerably compared to the Small Aral, with 6.9 in the surface water to 9.9 in the bottom water. The high ratio is caused by the precipitation of calcium carbonate and massive precipitation of gypsum, which is reflected by a decrease in $\mathrm{Ca}$ below the pycnocline. For comparison, the $\mathrm{Mg} / \mathrm{Ca}$ ratio in seawater is about 3.1. The observed increase in dissolved nutrients below the pycnocline is due to benthic release and reduced exchange across the pycnocline. The strong increase in POC and PN below the pycnocline in anoxic waters may be explained with increased abundance and productivity of chemoautotrophic bacteria.

Tschebas Bay is located in a shallow, almost isolated lagoon in the northernmost part of the Large Aral. The lagoon is connected with the other parts of the Large Aral by a small channel that allows only reduced exchange of water with the rest of the western basin. Due to its shallowness, we would expect a much higher salinity than measured. We suspect that salinity is balanced by some inflow of fresher water originating from the Syr Darya flowing south and by groundwater exfiltration. We observed exfiltration sites along the shoreline and at the slope of the cliff marked by green patches of reed.

Chernishov Bay is located at the northern tip of the western basin. We assume that it is influenced by water from the eastern basin, being flushed in through a small and shallow channel at favorable wind conditions from May to August (Zavialov et al., 2003). The most striking feature in Chernishov Bay is the appearance of a strong pycnocline and the presence of a huge anoxic water body below it. The wind-induced mixing layer reaches about 4-6 m depth. The relatively small surface area of the western basin prevents the build-up of high enough waves that might cause deeper wind mixing. Deep mixing is further prevented by the strong density gradient, resulting mainly from increase in salinity (Fig. 8a). A simple estimate may illustrate that even winter cooling is unlikely to cause an overturn in the density stratification. The increase in salinity across the pycnocline of about $20 \mathrm{~g} \mathrm{~kg}^{-1}$ per $\mathrm{m}$ would require a decrease in temperature of the surface mixed layer by $100{ }^{\circ} \mathrm{C}$ to outweigh the density difference (in seawater, a change in density caused by a change in salinity of $1 \mathrm{psu}$ is equivalent to a change in temperature of $5{ }^{\circ} \mathrm{C}$; Zavialov, personal communication). In addition, the presence of a cold intermediate layer, seen as remnant of winter cooling, and the presence of a saltier warmer bottom layer in summer let us assume that the water column does not mix completely during winter. Hence, our results give clear evidence that the bay became meromictic. However, its further verification is beyond the purpose of this paper and will be discussed elsewhere (Friedrich and Zavialov, in preparation).

We do not know the partitioning of sulphur in sulphide and sulphate in the anoxic bottom water body because the $\mathrm{H}_{2} \mathrm{~S}$ measurements failed. This partitioning might substantially depend on the duration of meromixis, lateral ventilation of the bottom water by influx of oxygenated eastern basin water and organic matter decomposition rates.

\subsection{Salt release from the sediments}

Up to now, to our knowledge, the salt release from the sediment to the water column was not considered in any salt budgets of the Aral Sea. Our results indicate a strong redissolution of salt from the sediment. It seems to be an important factor in the salt budget. According to our measurements, in the Small Aral, about $33.5 \mathrm{~g} \mathrm{SO}_{4}^{2-} \mathrm{m}^{-2}$ day $^{-1}$ and about $30.7 \mathrm{~g} \mathrm{Cl}^{-} \mathrm{m}^{-2}$ day $^{-1}$ are released from the sediment in summer. Assuming a surface of the Small Aral of about $2930 \mathrm{~km}^{2}$ gives a daily benthic input of 98,000 tons sulphate and of 89,000 tons chloride. A theoretical estimate may illustrate the importance of the benthic salt input to the water. Assuming an inventory (concentration $\times$ lake volume) of the Small Aral of 131 Mio tons sulphate and of 123 Mio tons chloride, it would take 3.6 and 3.8 years, respectively, to replace the water column inventory completely by benthic supply only.

In the Large Aral, the measured salt redissolution was 7-34 times higher for sulphate and 11-52 times 
higher for chloride than in the Small Aral. The lower range was derived from lagoon-like Tschebas Bay; the upper range was found in Chernishov Bay. In Chernishov Bay, $1143 \mathrm{~g} \mathrm{SO}_{4}^{2-} \mathrm{m}^{-2}$ day $^{-1}$ and 1626 $\mathrm{g} \mathrm{Cl}^{-} \mathrm{m}^{-2}$ day $^{-1}$ were released from the sediment into the water column. Assuming a surface of the western basin of about $5210 \mathrm{~km}^{2}$, the benthic sulphate input amounts to 5.96 Mio tons, and that of chloride to 8.5 Mio tons daily. For the western basin, we take a slightly different approach. Because we consider the western basin of being meromictic, the benthic salt input would accumulate in the bottom layer and not mix with waters above the pycnocline. As Zavialov et al. (2003) found the main pycnocline at about $22 \mathrm{~m}$ depth in $40 \mathrm{~m}$ deep waters, we assume in a very simplified estimate that the bottom water body might fill half the volume of the western basin $\left(38.1 \mathrm{~km}^{3}\right)$. Considering a bottom water inventory of 116 Mio tons sulphate and 154 Mio tons chloride, it would take 0.5 years to refill these inventories by benthic release only. We see that dissolution of salt from the sediment is even more important in the Large Aral. It further suggests an enormous accumulation of salt in the sediment. Ongoing analysis of shallow sediment cores and sedimentation rates will provide further information in the future. From the few measurements we cannot explain why the redissolution is much higher in the Large Aral, apart from the higher content in the sediment. We think that part of the high salinity in the bottom water of the western basin originates from benthic release. This process of salinization does, of course, interplay with the increase in salinity due to evaporation until salt minerals start to precipitate and redissolution of precipitates occurs.

Our work should be regarded as a pilot project towards the hydrogeochemical characterization of the present state of the changing Aral Sea and raises by no means the claim of being complete. Recommendations for further work include analysis of at least the parameters given above and sediment analysis in the eastern basin, in cross-sections further south in the western basin, close to Syr Darya and Amu Darya estuaries during different seasons. However, we are aware of the logistic difficulties that may arise from reaching the eastern basin in particular, and from conducting surveys during the cold season.

\section{Acknowledgements}

We wish to thank the CLIMAN team, and especially Francois Demory, for great support during the field campaign. Most of the chemical analyses were done in cooperation with AWI (many thanks to Antje Eulenberg) and EAWAG (many thanks to Ruth Stierli and Antonin Mares) while J.F. was still at GFZ. Special thanks to Sergey Stanichny from MHI for providing GIS-derived surface and volume values of the Aral Sea for August 2002. Financial support for J.F. during the field campaign is acknowledged from CLIMAN and Section 5 at GeoForschungsZentrum Potsdam.

\section{References}

Blinov, L., 1991. Hydrometeorology and Hydrochemistry of the Aral Sea. Leningrad (in Russian).

Boomer, I., Aladin, H., Plotnikov, I., Whatley, R., 2000. The palaeolimnology of the Aral Sea: a review. Quaternary Science Reviews 19 (13), 1259-1278.

Friedrich, J., Zavialov, P.O., in preparation. Is the western basin of the Aral Sea meromictic and forms permanent anoxic bottom water? Implications for the Ecosystem.

Letolle, R., Mainguet, M., 1996. Der Aralsee: Eine Ökologischen Katastrophe. Springer Verlag, Berlin.

Micklin, P.P., 1988. Desiccation of the Aral Sea-a water management disaster in the Soviet-Union. Science 241 (4870), $1170-1175$.

Seim, R., 1990. Geochemie der Hydrosphäre. In: Seim, R., Tischendorf, G. (Eds.), Grundlagen der Geochemie. Deutscher Verlag für Grundstoffindustrie, Leipzig.

Shnitnikov, A.V., 1983. The Aral Sea in the Holocene and Natural Tendencies of its Evolution. In: Maev, E.G. (Ed.), Paleogeography of the Caspia and Aral Seas in the Cenozoic: Part II, 106-118. Moscow.

Stanichny, S.V., Soloviev, D.M., Burdugov, V.M., Ratner, Yu.B., Stanichnaya, R.R., Horstmann, U., 2003. Aral Sea satellite observation, ARALKUM Progress Report.

Vollmer, M., et al., 2002. Physical and chemical properties of the waters of saline lakes and their importance for deep-water renewal: Lake Issyk-Kul, Kyrgystan. Geochimica et Cosmochimica Acta 6 (24), 4235-4246.

Zavialov, P.O., et al., 2003. Hydrographic survey in the dying Aral Sea. Geophysical Research Letters 30 (13), 2.1-2.4 (art. no.-1659). 